\title{
Induction of apoptosis in cancer cell lines by the Red Sea brine pool bacterial extracts
}

\author{
Sunil Sagar ${ }^{1}$, Luke Esau', Karie Holtermann², Tyas Hikmawan², Guishan Zhang ${ }^{2}$, Ulrich Stingl ${ }^{2}$, Vladimir B Bajic \\ and Mandeep Kaur ${ }^{*}$
}

\begin{abstract}
Background: Marine microorganisms are considered to be an important source of bioactive molecules against various diseases and have great potential to increase the number of lead molecules in clinical trials. Progress in novel microbial culturing techniques as well as greater accessibility to unique oceanic habitats has placed the marine environment as a new frontier in the field of natural product drug discovery.
\end{abstract}

Methods: A total of 24 microbial extracts from deep-sea brine pools in the Red Sea have been evaluated for their anticancer potential against three human cancer cell lines. Downstream analysis of these six most potent extracts was done using various biological assays, such as Caspase-3/7 activity, mitochondrial membrane potential (MMP), PARP-1 cleavage and expression of $\mathrm{YH} 2 \mathrm{Ax}$, Caspase-8 and -9 using western blotting.

Results: In general, most of the microbial extracts were found to be cytotoxic against one or more cancer cell lines with cell line specific activities. Out of the 13 most active microbial extracts, six extracts were able to induce significantly higher apoptosis (>70\%) in cancer cells. Mechanism level studies revealed that extracts from Chromohalobacter salexigens (P3-86A and P3-86B(2)) followed the sequence of events of apoptotic pathway involving MMP disruption, caspase-3/7 activity, caspase-8 cleavage, PARP-1 cleavage and Phosphatidylserine (PS) exposure, whereas another Chromohalobacter salexigens extract (K30) induced caspase-9 mediated apoptosis. The extracts from Halomonas meridiana (P3-37B), Chromohalobacter israelensis (K18) and Idiomarina loihiensis (P3-37C) were unable to induce any change in MMP in HeLa cancer cells, and thus suggested mitochondria-independent apoptosis induction. However, further detection of a PARP-1 cleavage product, and the observed changes in caspase-8 and -9 suggested the involvement of caspase-mediated apoptotic pathways.

Conclusion: Altogether, the study offers novel findings regarding the anticancer potential of several halophilic bacterial species inhabiting the Red Sea (at the depth of 1500-2500 m), which constitute valuable candidates for further isolation and characterization of bioactive molecules.

Keywords: Natural products, Cancer, Apoptosis, Marine bacteria, Deep-sea brine pools

\section{Background}

Over the last four decades, natural products have played an important role in drug discovery against cancer, one of the deadliest diseases in the world and the second most common cause of death in developed countries. Almost $47 \%$ of the anticancer drugs approved in the last 50 years were either natural products or synthetic molecules inspired by natural products [1]. However, due to

\footnotetext{
* Correspondence: mandeep.kaur@kaust.edu.sa

${ }^{1}$ Computational Bioscience Research Center, King Abdullah University of Science and Technology (KAUST), Thuwal 23955-6900, Kingdom of Saudi Arabia

Full list of author information is available at the end of the article
}

high toxicity and undesirable side effects associated with cancer drugs and, in particular, due to the development of resistance to chemotherapeutic drugs, there is a continuous need for novel drugs with greater therapeutic efficiency and/or with fewer side effects [2].

Marine microorganisms are considered to be an important source of bioactive molecules against various diseases and have great potential to increase the number of lead molecules in clinical trials. Approximately 3000 natural products have been isolated from marine microbial/algal sources and are described in Antibase [3]. Several of these 
microbial natural products have been evaluated in clinical trials for the treatment of various cancers [4,5]. Two cyanobacteria-derived antimicrotubule agents, i.e. dolastatin A and curacin A have been clinically evaluated against cancer and served as a lead structure for the synthesis of number of synthetic analogs/derivatives [6]. Another compound, salinosporamide $\mathrm{A}$, isolated from a marine-derived actinomycete, a highly potent irreversible inhibitor of $20 \mathrm{~S}$ proteasome, was also used in clinical trials as an anticancer agent [7]. Additionally, there is circumstantial evidence that several lead molecules in the clinical development pipeline, thought to originate from higher marine organisms, may actually be produced by marine microbes [8].

In the last decade, the deep sea has emerged as a new frontier in the isolation and screening of natural products, especially for cancer research $[9,10]$. With advancements in technology leading to greater accessibility as well as improvements in techniques used to culture microorganisms, deep sea environments are becoming 'hot spots' for new and unexplored chemical diversity for drug discovery [11]. Approximately 30,000 natural products have been isolated from marine organisms, yet less than $2 \%$ of those derive from deep-water marine organisms (http://dmnp. chemnetbase.com/intro/index.jsp). Of these, several cytotoxic secondary metabolites isolated from deep sea microorganisms have been described in the literature [9,12-14]. In our own efforts in this direction, cytotoxic and apoptotic potentials of marine halophilic bacteria isolated from the deep sea brine pools of the Red Sea, a largely unexplored resource in the area of natural product research, have been described previously [15], including the first report of cytotoxic activity of 'Sulfitobacter'.

In the present study, ethyl acetate extracts of 24 marine bacterial strains, isolated from the deep sea brine pools of the Red Sea, have been evaluated for their anticancer potential against HeLa (cervical carcinoma), DU145 (prostate carcinoma), and MCF-7 (breast adenocarcinoma) cell lines. The rationale behind choosing the cell lines lie in the severity and/or prevalence of various cancers in Saudi Arabia as well as around the world. The prevalence of breast cancer in the Kingdom of Saudi Arabia has increased from $10.2 \%$ in 2000 to $47.2 \%$ in 2007 [16]. Similarly, a screening program has demonstrated higher prevalence of prostate cancer [17] in the Kingdom. Another study anticipated a significant increase in proportion of cervical cancer [18] cases in the Kingdom. These cells lines are the also among the most robust cell line models used for in vitro drug screening. The evaluation of proapoptotic potential of highly cytotoxic extracts further revealed six highly potent extracts that were subjected to more detailed assays to infer the pathways involved in apoptotic mode of cell death in cancer cells.

\section{Methods}

\section{Field sampling}

The samples were retrieved from brine-seawater interfaces, brine layers, and sediments of deep-sea brine pools during KAUST Red Sea Expedition 2011. Water samples were collected using a rosette sampler equipped with 20 Niskin bottles (10 liter each) and a conductivitytemperature-depth (CTD) unit for monitoring salinity, temperature, transmission, and pressure (Idronout S.r.l, Italy). At each sampling site, approximately 180 litres of sample were collected and pre-filtered through a $5.0 \mu \mathrm{m}$ SMWP membrane (diameter $290 \mathrm{~mm}$; Millipore, Ireland) to remove suspended particles. A tangential flow filtration (TFF) system (Pellicon 2 Filter Acrylic Holder, Millipore, US) was used in order to filter-concentrate the samples. One liter of each concentrated sample was obtained after retention through a Durapore $0.1 \mu \mathrm{m}$ PVDF filter (Pellicon 2 Cassette Filter, Screen type C, size $0.5 \mathrm{~m} 2$, Millipore Corporation, MA, USA). These concentrated samples were stored in a dark bottle at $4^{\circ} \mathrm{C}$, and used as inoculum for microbial isolations. Sediment collection was performed by deploying a multicore sampling device into the bottom of the brine pools. The top layer of sediment (approximately $10 \mathrm{~cm}$ ) was cut, kept in anoxic containers in the dark, and were later used as inoculum for microbial isolations.

\section{Source of bacterial isolates}

A total of 24 bacterial strains were successfully isolated from deep-sea brine pools of the Red Sea. Nineteen of them were isolated from brine-seawater interfaces, one strain from brine, and four strains from sediments (Table 1). The inocula for bacterial isolation were collected from five different brine pools named Atlantis II (2194 m), Discovery Deep (2224 m), Kebrit Deep (1573 m), Nereus Deep (2458 m), and Erba Deep (2395 m) [19]. Each of the deep-sea brine pools has its unique physicochemical composition, with salinity up to $26 \%$, including notably high temperature, as well as high concentrations of heavy metals [20]. The Atlantis II Deep and the Discovery deep are considered as hot brines, with maximum temperatures $67.8^{\circ} \mathrm{C}$ and $44.8^{\circ} \mathrm{C}$, respectively. Brine-seawater boundaries in these brine pools are characterized by strong temperature and salinity gradients [21].

All of the bacterial strains isolated in this study were obtained by the streak plate method described elsewhere [34]. Eighteen strains grew in salinities of $10 \% \mathrm{NaCl}$ and the rest of the isolates grew well in salinities of $20 \% \mathrm{NaCl}$.

\section{PCR amplification}

Nucleic acids were extracted with Qiagen kit (DNeasy blood \& tissue kit, Qiagen, Germany) according to the instruction manual. PCR amplifications of the extracted DNA were performed in a $25 \mu \mathrm{l}$ reaction, each mixture 
Table 1 Taxonomic identification and collection location for $\mathbf{2 4}$ microbial strains

\begin{tabular}{|c|c|c|c|c|c|}
\hline Isolates & Source & Closest relative & Similarity (16S rRNA genes) & Accession number & Ref. \\
\hline P1-16A & Kebrit interface & Halomonas meridiana & $100 \%$ & AF212217 & [22] \\
\hline P1-16C & Kebrit interface & Idiomarina loihiensis & $98 \%$ & AE017340 & [23] \\
\hline P1-26A & Nereus brine & Virgibacillus salarius & $98 \%$ & NR_041270 & [24] \\
\hline P1-5 & Kebrit interface & Sediminimonas qiaohouensis & $99 \%$ & NR_044577 & {$[25]$} \\
\hline P2-13A & Kebrit sediment & Chromohalobacter salexigens & $99 \%$ & CP000285 & {$[26]$} \\
\hline P2-13B & Kebrit sediment & Halobacillus halophilus & $99 \%$ & HE717023 & {$[27]$} \\
\hline P2-16A & Kebrit interface & Halomonas meridiana & $99 \%$ & AF212217 & [22] \\
\hline P3-16A & Kebrit interface & Halomonas meridiana & $99 \%$ & AF212217 & [22] \\
\hline P3-16B & Kebrit interface & Halomonas meridiana & $99 \%$ & AF212217 & [22] \\
\hline P3-37A & Nereus interface & Halomonas meridiana & $99 \%$ & AF212217 & [22] \\
\hline P3-37B & Nereus interface & Halomonas meridiana & $99 \%$ & AF212217 & [22] \\
\hline P3-37C & Nereus interface & Idiomarina loihiensis & $91 \%$ & AE017340 & [23] \\
\hline P3-86A & Discovery interface & Chromohalobacter salexigens & $100 \%$ & CP000285 & {$[26]$} \\
\hline P4-13A & Kebrit sediment & Chromohalobacter salexigens & $99 \%$ & CP000285 & {$[26]$} \\
\hline P4-13B & Kebrit sediment & Staphylococcus sp. & $100 \%$ & JQ082193 & {$[28]$} \\
\hline P5-86A & Discovery interface & Idiomarina baltica & $99 \%$ & NR_027560 & [29] \\
\hline P5-86B & Discovery interface & Chromohalobacter salexigens & $99 \%$ & CP000285 & [26] \\
\hline P6-86 & Discovery interface & Chromohalobacter salexigens & $99 \%$ & CP000285 & [26] \\
\hline $\mathrm{K}-2$ & Atlantis II interface & Zunongwangia profunda & $100 \%$ & NR_074656 & {$[30]$} \\
\hline K-18 & Atlantis II interface & Chromohalobacter israelensis & $100 \%$ & AM945672 & {$[31]$} \\
\hline $\mathrm{K}-30$ & Atlantis II interface & Chromohalobacter salexigens & $99 \%$ & CP000285 & [26] \\
\hline $\mathrm{H} 102$ & Erba brine interface & Marinobacter adhaerens & $100 \%$ & NR_074765 & {$[32]$} \\
\hline $\mathrm{H} 105$ & Erba brine interface & Idiomarina zobellii & $99 \%$ & NR_024892 & [33] \\
\hline P3-86B (2) & Discovery interface & Chromohalobacter salexigens & $96 \%$ & CP000285 & {$[26]$} \\
\hline
\end{tabular}

containing $12.5 \mu$ l Promega PCR Master Mix 2x (Promega, USA), $1 \mu$ l (final concentration $0.5 \mu \mathrm{M}$ ) of primer 27bF (5'-AGAGTTTGATCMTGGCTCAG-3') and $1492 \mathrm{uR}\left(5^{\prime}\right.$-TACCTTGTTACGACTT-3'), $8.5 \mu \mathrm{l}$ RNAase\&DNAase free $\mathrm{H} 2 \mathrm{O}$ (Teknova), and DNA template. PCR was carried out in Mastercycler (Eppendorf, Germany) under following conditions: $94^{\circ} \mathrm{C}$ for $3 \mathrm{~min}$; 35 cycles of $94^{\circ} \mathrm{C}$ for $60 \mathrm{~s}, 53^{\circ} \mathrm{C}$ for $90 \mathrm{~s}, 72^{\circ} \mathrm{C}$ for $90 \mathrm{~s}$. A final extension was done for $7 \mathrm{~min}$ at $72^{\circ} \mathrm{C}$. The yield and quality of the PCR products were examined on $1 \%$ (wt/vol) agarose gel (SeaKem GTG, Lonza, USA) stained with SYBR Safe (Invitrogen, USA). All sequencing reactions were purified with Illustra Exostar 1-step (GE, Healthcare, UK) according to the manufacturer's protocol. The 16S rRNA sequences were determined using an ABI 3730xl capillary DNA sequencer (PE Applied Biosystems), at Core Laboratory KAUST, Saudi Arabia.

\section{Bacterial biomass}

The concentrated samples were inoculated onto three different agar media, plate count agar (Teknova), marine agar 2216 (Difco), and R2A agar (Oxoid), which were supplemented with either $10 \%$ or $20 \% \mathrm{NaCl}(\mathrm{w} / \mathrm{v})$ to adjust salinity. The plates were incubated at $30^{\circ} \mathrm{C}$ for up to three weeks and inspected daily. Colonies from various agar plates were picked based on difference in colony morphology. Pure isolates of these colonies were obtained after three successive transfers to the fresh agar media. Taxonomic identifications of the isolates were based on $16 \mathrm{~S}$ rRNA gene sequencing. 16S rRNA gene amplification and sequencing steps were performed according to [35]. Sequence similarity was analyzed using BLASTN search program to identify the strains to their closest relatives in GenBank database (http://www.ncbi.nlm.nih.gov/BLAST). Bacteria were inoculated in 1 liter of Marine Broth (Difco) supplemented with $\mathrm{NaCl}$ to collect the biomass, and then were incubated at $30^{\circ} \mathrm{C}$ in a shaking incubator. After two weeks of incubation, bacterial cultures were harvested by centrifugation at ambient temperature for an hour (h). The centrifugation step was repeated by adding sterile water at the same salinity to wash the pellets. Cell pellets were stored at $-80^{\circ} \mathrm{C}$ until used for extract preparation.

\section{Extract preparation}

Ethyl acetate extracts of 24 strains of marine bacteria were prepared at a concentration of $100 \mathrm{mg} / \mathrm{mL}$ (speedvac dried 
material $/ \mathrm{mL}$ of solvent). Solutions were sonicated with ultra-sound probe (Biologics Inc., Model $150 \mathrm{~V} / \mathrm{T}$ ) for $5 \times$ 2 minutes on ice. The solutions were centrifuged at $10000 \mathrm{~g}$ for 15 minutes; the supernatants were recovered and stored at $-20^{\circ} \mathrm{C}$.

\section{Cell culture}

MCF-7 (Breast Adenocarcinoma), HeLa (Cervical carcinoma), and DU145 (Prostate carcinoma) were obtained from the American Type Cell Culture Collection (ATCC, Manassas, VA). All cell lines were cultured in DMEM (Dulbecco's Modified Eagle's Medium), supplemented with $10 \%$ FCS (Fetal calf serum), penicillin $(100 \mathrm{U} / \mathrm{mL})$ and streptomycin $(100 \mu \mathrm{g} / \mathrm{mL})$ at $5 \% \mathrm{CO}_{2}$ in a $37^{\circ} \mathrm{C}$ incubator.

\section{MTT assay}

The cytotoxicity of marine bacterial extracts was estimated by MTT (3-(4, 5-Dimethylthiazol-2-yl)-2, 5diphenyltetrazolium bromide) assay. Cells were seeded at a density of $2.5 \times 10^{3}$ cells per well in a 384-well culture plates and treated with 200 and $500 \mu \mathrm{g} / \mathrm{mL}$ marine bacterial extracts for $48 \mathrm{~h}$. Following incubation with extracts, $5 \mu \mathrm{L}$ of sterile MTT $(5 \mathrm{mg} / \mathrm{mL})$ dissolved in PBS was added to each well and incubated with cells for $4 \mathrm{~h}$ followed by the addition of $30 \mu \mathrm{L}$ of solubilization solution (10\% SDS, $10 \mathrm{mM} \mathrm{HCl})$, which was further incubated with cells for $16 \mathrm{~h}$ at $37^{\circ} \mathrm{C}$. The OD (optical density) of each well was measured at $595 \mathrm{~nm}$ using a microtiter plate reader (BMG Labtech PHERAstar FS, Germany) and results were analyzed using Microsoft Office Excel(.)

\section{APOPercentage assay}

HeLa cells were seeded in 96-well plates at a density of $5 \times 10^{3}$ cells per well in quadruplicate in $90 \mu \mathrm{L}$ of media. After $24 \mathrm{~h}$, cells were treated with marine bacterial extracts diluted in complete DMEM to a final concentration of $500 \mu \mathrm{g} / \mathrm{mL}$ and incubated at $37^{\circ} \mathrm{C}$ for 24 and $48 \mathrm{~h}$. Cells were treated with $10 \mathrm{mM} \mathrm{H}_{2} \mathrm{O}_{2}$ for 30 minutes as a positive control. The cells were lifted and stained with APOPercentage dye (Biocolor, UK). Percentage of cells stained positive for apoptosis was determined with a high throughput flow cytometer (HTFC) Screening System (IntelliCyt Corporation, Albuquerque, NM). Cells were gated for FSC-H, SSC-H and in the FL-2H channel recording a minimum of 1000 events per well.

\section{Microscopy}

The morphological evaluation and photography of cells after treatment with extracts was done in 96-well plates using Primo Vert inverted microscope (Carl Zeiss, Inc.)

\section{MMP assay}

HeLa cells were seeded in 96-well plates at a density of $5 \times 10^{3}$ cells per well in quadruplicate in $90 \mu \mathrm{L}$ of media and allowed to settle overnight. Next day, cells were treated with $500 \mu \mathrm{g} / \mathrm{mL}$ marine bacterial extracts for 12 and $16 \mathrm{~h}$ and stained with $50 \mu \mathrm{M}$ cyanine dye JC-1 (5,5',6,6' -tetrachloro-1,1' '3,3' '-tetraethylbenzimi- dazolylcarbocyanine iodide, Life Technologies, UK) for $1 \mathrm{~h}$. Cells were analyzed by HTFC system by plotting FL2-H vs. FL-1H and applying a quadrant gate to determine JC-1 aggregates (red) and monomers (green).

\section{Caspase assay}

HeLa cells were seeded at a density of $2.5 \times 10^{3}$ cells per well in $20 \mu \mathrm{L}$ of media in 384-well plates. After $24 \mathrm{~h}$, $5 \mu \mathrm{L}$ of marine bacterial extract $(500 \mu \mathrm{g} / \mathrm{mL})$ was added and incubated for a further $16 \mathrm{~h}$. Caspase-3/7 activity was estimated using ApoTox-Glo kit (Promega) following the manufacturer's instructions. Luminescence was measured using a luminescence plate reader (BMG Labtech PHERAstar FS, Germany). The results were normalized to cell viability (measured using MTT assay).

\section{Western blotting}

HeLa cells were seeded at a density of $3 \times 10^{5}$ cells per well in 6-well plates and left overnight to settle. Cells were treated with $500 \mu \mathrm{g} / \mathrm{mL}$ of marine bacterial extracts for 12 and $24 \mathrm{~h}$. Protein was harvested with RIPA lysis buffer $(150 \mathrm{mM} \mathrm{NaCl}, 1 \%$ Triton X 100, 0.1\% SDS, $10 \mathrm{mM}$ Tris $\mathrm{pH} 7.5,1 \%$ sodium deoxycholate) and quantitated with a BCA protein determination kit (Pierce Thermo Scientific). 10-20 $\mu \mathrm{g}$ of protein lysate was subjected to electrophoresis on $12 \%$ SDS page gels, transferred to nitrocellulose membrane and probed with Caspase-8 (Sigma), Caspase-9 (Thermo Scientific), PARP-1 (Trevigen) and pH2Ay (Enzo Life Technologies) antibodies. $\beta$-Tubulin (Santa Cruz) was used as a loading control.

\section{Z-factor}

Z-factor was determined for each assay and a Z-factor score of $\geq 0.6$ was recorded indicating good to excellent robustness for assays [36].

\section{Results}

\section{Microbial isolates from the Red Sea}

Twenty-four strains of marine bacteria were isolated from the samples collected from brine-seawater interfaces, brine layers, and sediments of five deep-sea brine pools of the Red Sea. Taxonomic classification and location of collection for these microbial strains is presented in Table 1. The samples were extracted by using ethyl acetate and evaluated for their anticancer potential through various biological assays. 


\section{Antiproliferative activities of marine bacterial extracts} The antiproliferative effect of 24 marine bacterial extracts was evaluated in vitro by MTT assay against three human cancer cell lines, i.e. DU145 (prostate cancer), MCF-7 (breast cancer) and HeLa (cervical cancer). The cancer cells were exposed to marine extracts for $48 \mathrm{~h}$ (Table 2), at the concentrations of 200 and $500 \mu \mathrm{g} / \mathrm{mL}$. In general, most of the microbial extracts were able to induce growth inhibition in one or more cancer cell line/s; however, extracts P1-5, P2-13B, P3-37B, H-102, P3-86B and P3-86A displayed up to $60 \%$ growth inhibition in DU145 cell line at $500 \mu \mathrm{g} / \mathrm{mL}$. Similarly in MCF-7 cells, several microbial extracts were found to be cytotoxic at the same concentration. HeLa emerged as the most sensitive cell line as 13 microbial extracts inhibited $30 \%$ or more cell growth at $500 \mu \mathrm{g} / \mathrm{mL}$ concentration (Table 2). Extracts from Halomonas meridiana (P3-37B) and Chromohalobacter salexigens (K-30 and P3$86 \mathrm{~B}(2))$ displayed the highest growth inhibition, i.e. $>85 \%$.
Microbial extracts with more than $30 \%$ growth inhibition were chosen for further apoptotic analysis. HeLa was chosen for the downstream analysis of selected microbial extracts due to its higher sensitivity to most of the extracts.

\section{Apoptotic cell death in HeLa cells}

Since anticancer agents are known to induce apoptosis in cancer cells and apoptosis biomarkers are being increasingly used in clinical trials [37], a total of 13 extracts showing significant cytotoxicity were tested for their proapoptotic potential in HeLa cells by using APOPercentage assay. Seven extracts were found to induce apoptosis at $500 \mu \mathrm{g} / \mathrm{mL}$ concentration after $48 \mathrm{~h}$ (Figure 1A). Extracts from Chromohalobacter salexigens (P3-86A, K30, P3-86B(2)), Chromohalobacter israelensis (K18), Halomonas meridiana (P3-37B) and Idiomarina loihiensis (P3-37C) induced more than

Table 2 Evaluation of antiproliferative effects of marine bacterial extracts on various cancer cell lines

\begin{tabular}{|c|c|c|c|c|c|c|}
\hline \multirow[t]{2}{*}{ Strain } & \multicolumn{2}{|c|}{ HeLa } & \multicolumn{2}{|c|}{ MCF-7 } & \multicolumn{2}{|c|}{ DU145 } \\
\hline & $200 \mu \mathrm{g} / \mathrm{mL}$ & $500 \mu \mathrm{g} / \mathrm{mL}$ & $200 \mu \mathrm{g} / \mathrm{mL}$ & $500 \mu \mathrm{g} / \mathrm{mL}$ & $200 \mu \mathrm{g} / \mathrm{mL}$ & $500 \mu \mathrm{g} / \mathrm{mL}$ \\
\hline P1-16A & 8.0 & 16.2 & 0 & 0 & 3.2 & 1.0 \\
\hline P3-16A & 12.9 & 32.8 & 0 & 0 & 4.9 & 6.1 \\
\hline P5-86B & 2.8 & 2.8 & 0 & 0 & 0.8 & 8.3 \\
\hline $\mathrm{H} 102$ & 54.6 & 37.0 & 21.7 & 18.0 & 3.0 & 2.0 \\
\hline P3-16B & 0 & 0 & 0 & 0 & 11.7 & 14.4 \\
\hline P6-86 & 0 & 0 & 0 & 0 & 2.0 & 6.8 \\
\hline P2-16A & 0 & 0 & 0 & 0 & 7.3 & 6.0 \\
\hline P1-26A & 0 & 0 & 0 & 0 & 3.9 & 2.7 \\
\hline P5-86A & 0 & 0 & 0 & 0 & 1.4 & 10.2 \\
\hline P3-86B(2) & 0 & 95.2 & 0 & 0 & 4.5 & 7.2 \\
\hline P3-86A & 31.9 & 39.8 & 32.1 & 35.3 & 2.3 & 3.0 \\
\hline P1-5 & 27.2 & 56.3 & 33.4 & 54.0 & 52.1 & 59.9 \\
\hline P1-16C & 30.7 & 35.3 & 33.5 & 51.1 & 41.4 & 47.0 \\
\hline $\mathrm{H} 105$ & 17.1 & 19.0 & 16.3 & 23.4 & 7.4 & 7.5 \\
\hline P3-37A & 1.1 & 13.6 & 16.4 & 28.5 & 24.3 & 28.8 \\
\hline K2 & 1.4 & 15.5 & 13.2 & 12.4 & 14.6 & 11.9 \\
\hline P4-13A & 0 & 6.9 & 4.2 & 3.8 & 0 & 12.3 \\
\hline P3-37C & 0 & 4.9 & 22.1 & 34.8 & 21.7 & 1.5 \\
\hline K18 & 16.0 & 36.6 & 11.6 & 37.0 & 24.1 & 45.3 \\
\hline P3-37B & 12.3 & 43.6 & 32.5 & 89.8 & 41.8 & 34.6 \\
\hline K30 & 24.7 & 28.4 & 27.9 & 88.2 & 18.6 & 30.4 \\
\hline P2-13B & 35.3 & 50.5 & 39.5 & 51.4 & 62.5 & 60.7 \\
\hline P4-13B & 8.2 & 8.4 & 29.0 & 37.7 & 44.7 & 39.8 \\
\hline
\end{tabular}

The growth of cells was inhibited in a dose-dependent manner at concentrations of 200 and $500 \mu \mathrm{g} / \mathrm{mL}$ after $48 \mathrm{~h}$. MTT assay was used to assess the growth inhibitory potential of extracts and is presented as percent growth inhibition relative to untreated cells. The Z-factor for this experiment was calculated to be 0.76 . The extracts selected for apoptosis analysis are presented in bold letters. 


\section{(A)}

\section{HeLa cells treated with Marine Bacterial Extracts for $48 \mathrm{~h}$}

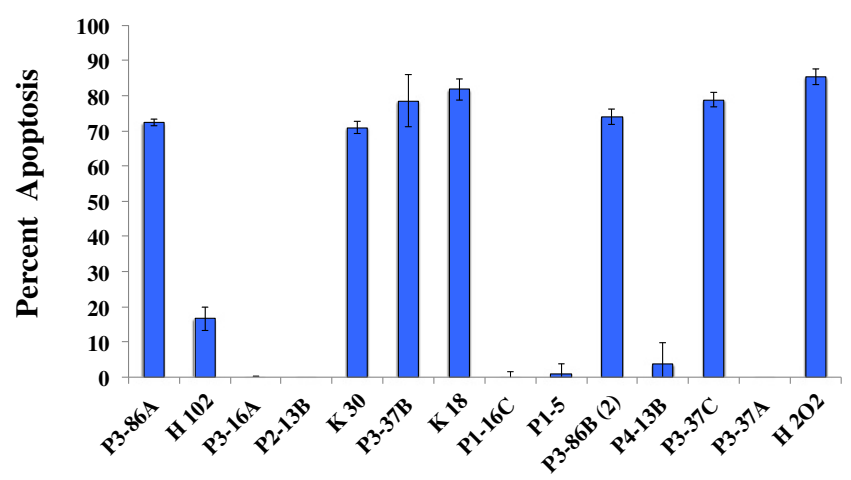

(B)

HeLa cells treated with Marine Bacterial Extracts for 24 h

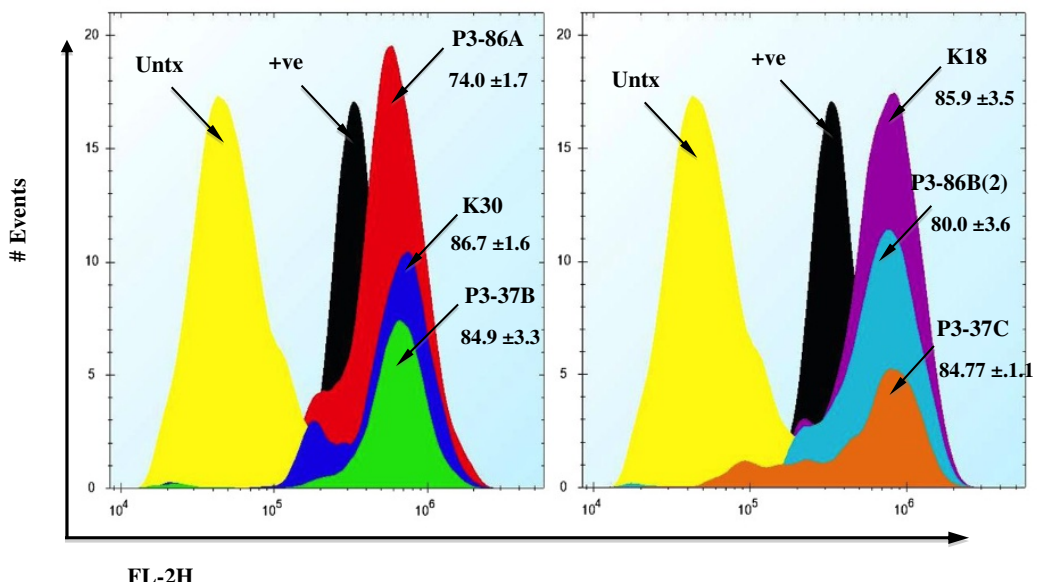

(C)

$\begin{array}{llllll}\text { Untx } & \text { P3-86A } & \text { K30 } & \text { P3-37B } & \text { K18 } & \text { P3-86B (2) }\end{array}$

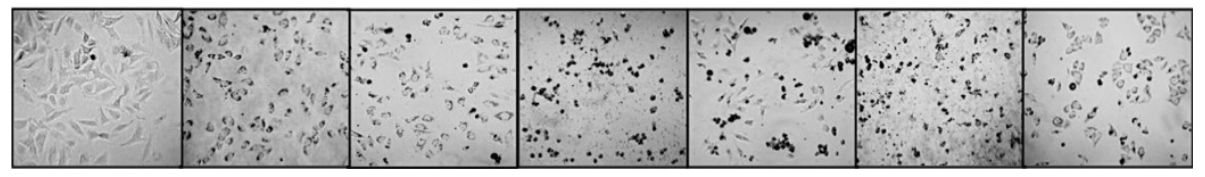

Figure 1 Apoptosis induction in HeLa cells after treatment with marine bacterial extracts. Detection of externalization of PS from cell membrane was done using APOPercentage assay. Cells were stained with dye and fluorescence was measured using flow cytometry. The photographs were taken by using inverted microscope. Apoptosis is shown as the percentage of cells that uptake APOPercentage dye relative to untreated cells. A) Cells were treated with $\mathrm{H}_{2} \mathrm{O}_{2}$ or extracts at a final concentration of $500 \mu \mathrm{g} / \mathrm{mL}$ for $48 \mathrm{~h}$, and $\mathbf{B}$ ) for $24 \mathrm{~h}$. The Z- factor was calculated to be 0.68 and 0.77 for $48 \mathrm{~h}$ and $24 \mathrm{~h}$ experiments, respectively. C) The morphology of cancer cells after $24 \mathrm{~h}$ of treatment with chosen extracts.

$70 \%$ apoptosis in HeLa cells. Therefore, six most potent extracts (P3-86A, K30, P3-37B, K18, 2 and P337C) were also evaluated for apoptosis at $24 \mathrm{~h}$ (Figure 1C), and chosen for further investigation to confirm the pathway of induced apoptotic cell death in
HeLa cells. The cells were also evaluated for their morphological features of apoptosis using microscopy. Visual inspection showed that the morphological changes were visible within few hours after treatment of certain extracts (Figure 1C). 


\section{Effects of extracts on MMP}

The changes in MMP were used to evaluate its role in initiating apoptosis. In the present study, MMP was assessed using JC- 1 dye. The JC- 1 is a membrane permeable dye that has a unique characteristic of attraction to negative charge potential. The electron transport chain in energized mitochondria (normal MMP) attracts JC- 1 dye into mitochondria where it accumulates to form J-aggregates (fluoresces red at $595 \mathrm{~nm}$ ), while mitochondria with disrupted membrane potential (apoptotic cells) cannot accumulate JC-1, thus leaving the dye in the monomeric form (fluoresces green at $530 \mathrm{~nm})$. Extracts from Chromohalobacter salexigens (P3-86A and $\mathrm{P} 3-86 \mathrm{~B}(2)$ ) were only able to induce changes in MMP by $45 \%$ and $29 \%$ respectively (Figure 2) confirming their role in mitochondrialmediated apoptosis.

\section{Activation of caspases in response to treatment with extracts}

To gain insights into the potential mechanisms of apoptosis involved, caspase-3/7 activity as well as protein expression of caspase- 8 and -9 were measured for the six most potent extracts in HeLa cells after $16 \mathrm{~h}$ of treatment. All six extracts were able to activate caspase-3/7 and can be grouped further into two categories of 'active' and 'highly active' depending on the fold increase in observed caspase-3/7 activity as compared to untreated cells (Figure 3). Microbial extracts from P3-86A, P3-37B and K18 showed $<10$ fold increase in caspase-3/7 activity and were termed as active (in the range of 1.7-6.0 folds) while extracts from Chromohalobacter salexigens (K30, P3-86B(2)) and Idiomarina loihiensis (P3-37C) were considered highly active due to their remarkably high caspase-3/7

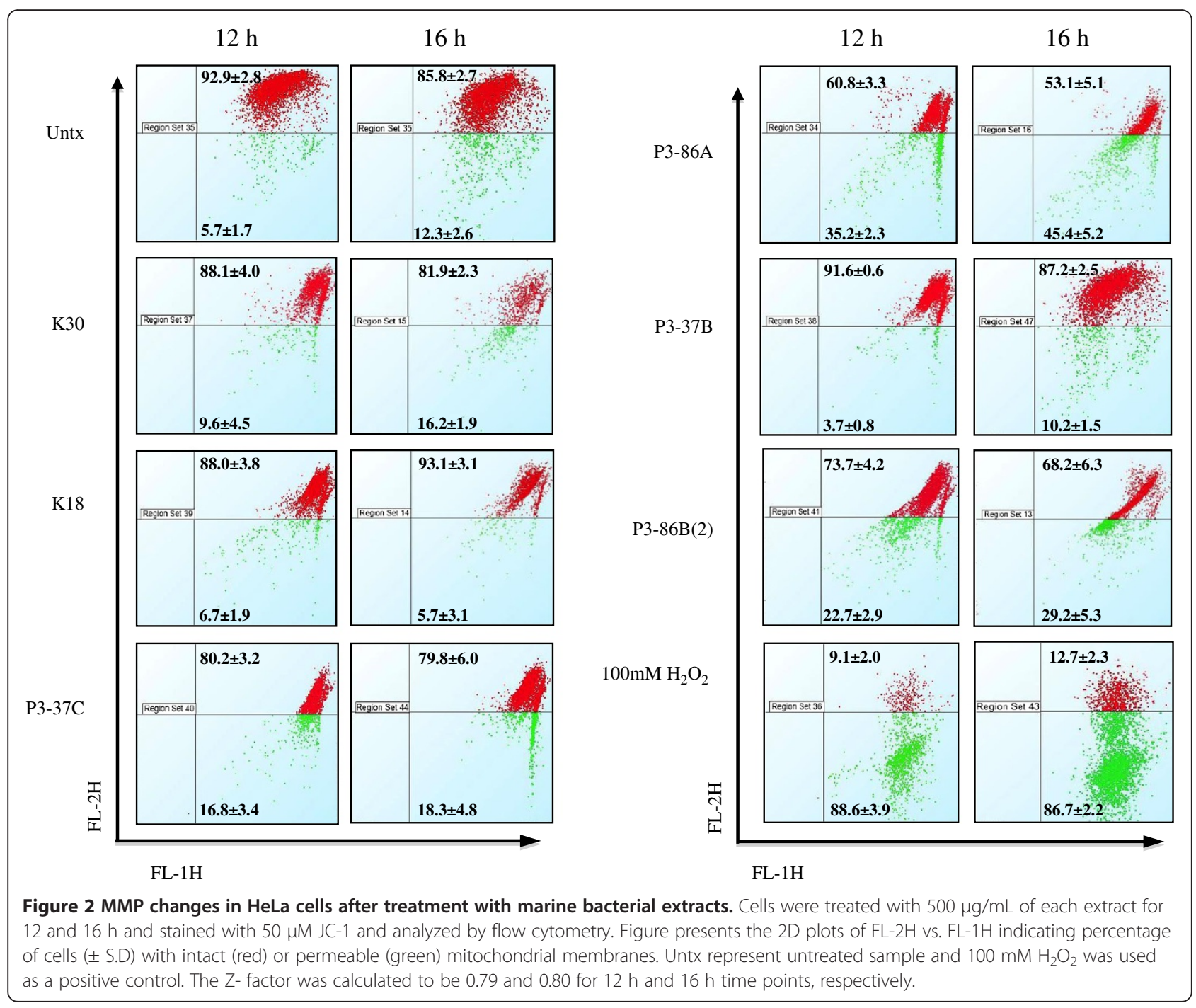




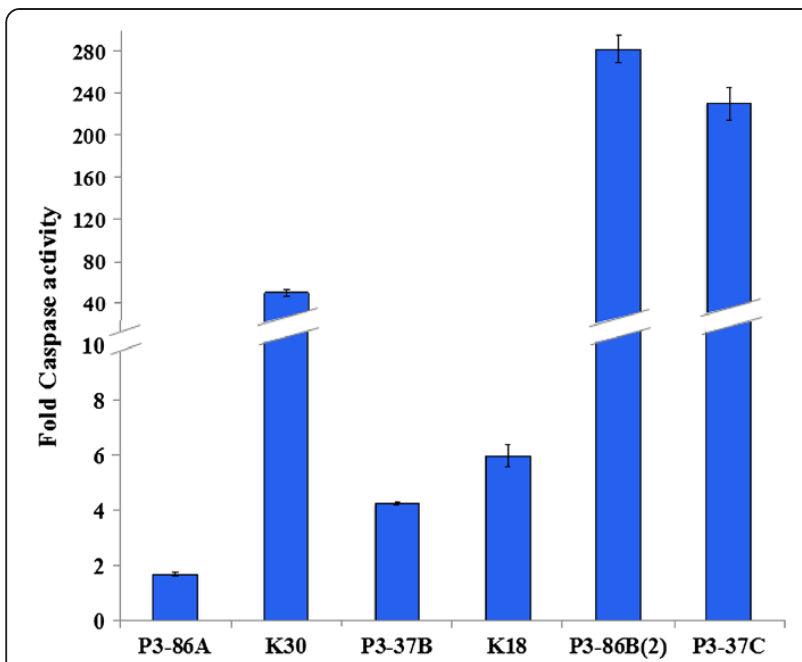

Figure 3 Caspase-3/7 activity in HeLa cells after treatment with marine bacterial extracts. Cells were treated with $500 \mu \mathrm{g} / \mathrm{mL}$ extracts for $16 \mathrm{~h}$ and caspase-3/7 activity was estimated by measuring luminescence using ApoTox-Glo kit (Promega). The caspase-3/7 activity is represented as fold-change in activity when compared to untreated cells.

activity ( $\geq 50$ fold increase) as compared to untreated cells. All extracts except Chromohalobacter salexigens (P3-86A) showed significant reduction in full-length caspase-9. Similarly, cleavage of caspase-8 (cl-Caspase-8) was observed in cancer cells treated with all other extracts except Chromohalobacter salexigens extract (K30).

\section{PARP-1 cleavage through caspases}

The concerted action of caspases- 3 and -7 lead to PARP-1 cleavage in response to DNA damaging agents $[38,39]$ and is considered as a hallmark of apoptosis $[40,41]$. To further explore that induced apoptosis in HeLa cells was via PARP-1 cleavage, western blotting was performed. Figure 4 shows an elevation in the cleaved fragment of PARP-1 $(85 \mathrm{kDa})$ in a time dependent manner for the extracts from Chromohalobacter salexigens ( $\mathrm{P} 3-86 \mathrm{~B}(2))$, Chromohalobacter israelensis (K18), Halomonas meridiana (P3-37B) and Idiomarina loihiensis (P3-37C). The PARP-1 cleavage is quite significant after $12 \mathrm{~h}$ of treatment; however only a cleaved fragment was noticeable for these extracts (except for P3-37B) at $24 \mathrm{~h}$. These observations confirmed the involvement of caspases mediated PARP-1 cleavage in response to the treatment with these four marine extracts in HeLa cells.

\section{Activation of $\mathrm{\gamma H} 2 \mathrm{Ax}$, a DNA damage marker}

$\gamma \mathrm{H} 2 \mathrm{Ax}$ is a variant of $\mathrm{H} 2 \mathrm{~A}$ histone and is phosphorylated at serine 139 in the presence of DNA double-stand breaks caused by DNA damage [42] and DNA fragmentation during apoptosis [43]. Substantial DNA damage was measured in HeLa cancer cells within $12 \mathrm{~h}$ of treatment with extracts P3-37B, P3-37C, P3-86B(2) and K18 (Figure 4), confirming their role as DNA damaging agents.

\section{Discussion}

In the present study, 24 extracts of marine bacteria isolated from the deep-sea brine pools of the Red Sea were evaluated for their cytotoxic effects against three human cancer cell lines. Out of all, 13 extracts were found to be significantly active against one or more cancer cell lines indicating their cell line specific behavior. The cell line specific activity of the extracts may be due to the presence of particular secondary metabolites and/or the different mechanisms of action of programmed cell death prevalent in different cancer cell lines.

Apoptosis or programmed cell death in multicellular organisms maintain the homeostasis by eliminating unwanted or defective cells [44]. It is well known that inefficient apoptosis contribute to several human malignancies

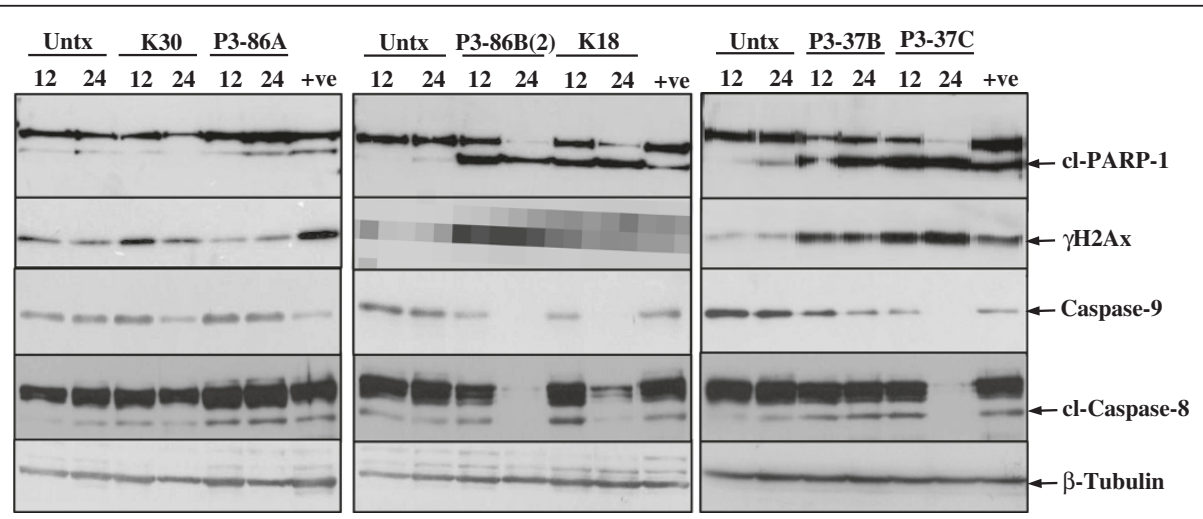

Figure 4 Western blot analysis of PARP-1 cleavage, phosphorylated $\mathrm{yH} 2 \mathrm{AX}$, Caspase-8 and -9 in HeLa cells after treatment with marine bacterial extracts. Protein lysates of HeLa cells treated with $500 \mathrm{\mu g} / \mathrm{mL}$ of each extract for 12 and $24 \mathrm{~h}$ were subjected to western blotting probing for cleaved PARP-1 (cl-PARP-1), procaspase-9, cleaved caspase-8 and $\mathrm{yH} 2 \mathrm{Ax}$. Cells treated with $400 \mathrm{nM}$ docetaxel for $24 \mathrm{~h}$ were used as a positive (+ve) control, Untx represent untreated control and $\beta$-tubulin was used as a loading control. 
$[45,46]$; therefore, the identification of anticancer agents that induce cell death via apoptosis is one of the attractive strategies for chemotherapy [47]. The extracts from Chromohalobacter salexigens (P3-86A, K-30, P3-86B(2)), Halomonas meridian (P3-37B), Idiomarina loihiensis (P3-37C) and Chromohalobacter israelensis (K-18) were found to be most actively inducing apoptosis in HeLa cells (Figure 1). These extracts induced either one or more apoptosis related molecular changes such as cell shrinkage, PS exposure by membrane flipping, caspase- $3 / 7,-8$ or -9 activation, PARP-1 cleavage (representing DNA fragmentation) and increase in phosphorylation of $\gamma \mathrm{H} 2 \mathrm{Ax}$ (indicating DNA damage). Not much work has been published on the isolation of cytotoxic compounds from these microbial species. Our group [15] and others [48-50] have shown previously that Halomonas species produce metabolites that have the potential to kill cancer cells. Idiomarina loihiensis is an aerobic heterotrophic bacterium capable of catabolizing amino acids as a primary energy source [23]. In PubMed, there are only 10 articles on Idiomarina loihiensis and most of these focus on describing its isolation and characterization [51], metabolism [23], and biofilm forming capabilities [52]. No study to date has focused on evaluating the bioactive potential of this species.

In the present study, extract from Idiomarina loihiensis (P3-37C) displayed caspase-dependent apoptosis in HeLa cells where a strong (229 fold) increase in caspase-3/7 activity was observed. Extract from K-18 also induced caspase-dependent apoptosis in our study, which showed $100 \%$ similarity to Chromohalobacter israelensis. Chromohalobacter israelensis is a euryhaline halophile shown to change its concentration of unsaturated fatty acids in response to change in salt concentration, thus providing a mechanism for halophiles to tolerate environmental stresses [53]. Nothing has been reported so far regarding cytotoxic potential of this strain. Isolates P3-86A, K-30 and $\mathrm{P} 3-86 \mathrm{~B}(2)$ were found to have high $16 \mathrm{~s}$ similarity with Chromohalobacter salexigens. This is one of the most investigated strain (out of the four we are reporting here) as a PubMed search on 15th July 2013 displayed 33 articles on Chromohalobacter salexigens. The Work to date has focused broadly on compatible solutes [54-57] and metabolism [58-61]. To the best of our knowledge, no attempt has been made to assess the cytotoxicity potential of these bacteria.

The key objectives of the present study were to estimate the proapoptotic potential of novel halophytes isolated from the brine pools of the Red Sea and to shed light on the mechanism of apoptosis induction in cancer cells. We investigated the mode of induction of apoptosis by marine bacterial extracts by targeting the intrinsic and extrinsic pathways in human cervical cancer cell line (HeLa). Broadly, apoptosis is known to work through two pathways, i.e., mitochondria-mediated intrinsic pathway and death receptors mediated extrinsic pathway [62]. Intrinsic pathway is activated by either permeabilization of the outer membrane of mitochondria leading to disrupted MMP, or via DNA damage. Both routes activate caspase-9 and consequently lead to activation of caspase-3 [63]. Extrinsic pathway involves interaction of ligands (Fas and TNF-alpha) to their transmembrane receptors [64], thus activating caspase-8, which further activates caspase-3 directly [65] or by first activating intrinsic pathway followed by activation of caspase-3 [66]. Intrinsic- and extrinsicpathways merge at caspase-3, which further cleaves PARP1 and results in apoptosis [67]. The results of pathway level investigations of the marine bacterial extracts are summarized in Table 3.

We reveal here that extracts from Chromohalobacter salexigens (P3-86A and P3-86B(2)) induced MMP disruption, caspase-3/7 activation, PARP-1 cleavage and PS exposure. PS externalization represents an early event during execution phase of apoptosis occurring between caspases activity and nuclear condensation [68]. Further investigation into the expression of caspase- 8 and -9 determined the cleavage of caspase- 8 after treatment with extract P3-86A, while no change in expression of full-length caspase-9 was observed, (Figure 4). This confirms that P3-86A induces apoptosis through extrinsic pathway. Extract P3-86B(2) was found to reduce

Table 3 Summary of the results of PS exposure apoptosis assay, Caspase-3/7 activity, MMP changes, PARP-1 and Caspase-8 cleavage, full-length Caspase- 9 and $\mathrm{\gamma H} 2 \mathrm{Ax}$ protein expression in HeLa cells treated with $500 \mathrm{\mu g} / \mathrm{mL}$ concentration of extracts

\begin{tabular}{|c|c|c|c|c|c|c|c|}
\hline Extract & $\begin{array}{l}\text { PS exposure (percentage of } \\
\text { stained cells) }\end{array}$ & $\begin{array}{c}\text { Caspase-3/7 activity (fold } \\
\text { change) }\end{array}$ & MMP & $\begin{array}{l}\text { PARP-1 } \\
\text { cleavage }\end{array}$ & $\mathrm{pH} 2 \mathrm{Ax}$ & $\begin{array}{l}\text { Caspase-9 } \\
\text { reduction }\end{array}$ & $\begin{array}{c}\text { Caspase-8 } \\
\text { cleavage }\end{array}$ \\
\hline P3-86A & $+(73.95 \%)$ & $+(1.7)$ & + & + & - & - & + \\
\hline $\mathrm{K} 30$ & $+(86.74 \%)$ & $+(50.0)$ & - & - & + & + & - \\
\hline P3-37B & $+(84.89 \%)$ & $+(4.2)$ & - & + & + & + & + \\
\hline K18 & $+(85.85 \%)$ & $+(5.9)$ & - & + & + & + & + \\
\hline $\begin{array}{l}\text { P3-86B } \\
\text { (2) }\end{array}$ & $+(80.01 \%)$ & $+(282.1)$ & + & + & + & + & + \\
\hline P3-37C & $+(84.77 \%)$ & $+(229.7)$ & - & + & + & + & + \\
\hline
\end{tabular}

'十' represents a positive observation, whereas '-'represents a negative observation. 
expression of both full-length caspase- 8 and -9 (Figure 4), thus suggesting that both extrinsic and extrinsic pathways of apoptosis are involved in its mechanism of action. The extracts from Halomonas meridiana (P3-37B), Chromohalobacter israelensis (K18) and Idiomarina loihiensis (P3$37 \mathrm{C})$ were unable to induce any change in MMP in HeLa cancer cells and thus suggest the mitochondrialindependent apoptotic induction. The expression of both full-length caspase- 8 and -9 was significantly reduced thus confirming the involvement of these initiator caspases in apoptosis induction. DNA damage was also observed in cancer cells which is known to activate Caspase-9 $[69,70]$ leading to intrinsic apoptosis in the absence of mitochondrial-mediated pathway. In case of Chromohalobacter salexigens (K30) extract, in spite of a 50-fold increase in caspase-3/7 activity and PS externalization, K-30 neither caused any change in MMP nor cleavage of PARP-1, although a slight increase in $\gamma \mathrm{H} 2 \mathrm{Ax}$ was observed indicating DNA damage. It is well documented that PARP activity is induced in response to DNA strand breaks in cells that have been exposed to DNAdamaging agents [71]. Although it is widely accepted that PARP is specifically cleaved during apoptosis [72] by caspase-3 [73] and caspase-7 [74], but studies have also shown that PARP activity [75], activation of PARPcleaving enzymes [76] and cleavage of PARP-1 [77] are not essential for induction of apoptosis. In another study, uncleavable PARP has been shown to accelerate apoptosis and necrosis [78] with possible explanation that uncleavable PARP may lead to imbalanced energy pool by depleting NAD + and ATP pools, which further disrupts MMP, thus releasing proapototic factors from mitochondria. In our study, K30 did not disrupt MMP and hence the above mentioned explanation does not clarify the mechanism of apoptosis induction by K30. Caspase9 was significantly reduced at $24 \mathrm{~h}$ after K30 induction. This suggests that the K30 induces apoptosis in cancer cells through intrinsic pathway where DNA damage leads to activation of caspase- 9 that further contributes to the observed activities of caspase-3/7 and PS exposure.

In the last decade, phosphorylated gamma-H2AX $(\gamma \mathrm{H} 2 \mathrm{Ax})$ has emerged as a marker of DNA damage [79] and drug response in cancer patients $[80,81]$. The chemicals/drugs that lead to DNA damage in cells are known as 'genotoxic drugs'. Several genotoxic compounds such as cisplatin, carboplatin, oxaliplatin, methotrexate, doxorubicin, daunorubicin etc., are currently being used in the treatment of various types of cancers [82]. The extracts tested in the present study also showed strong DNA damage as measured using $\gamma \mathrm{H} 2 \mathrm{Ax}$, which shows that these extracts may contain compounds that could find potential therapeutic use in cancer patients. This study opens up avenues for identifying new DNA damaging compounds from deep-sea bacteria.

\section{Conclusions}

This study reports for the first time the cytotoxic activities of several halophilic bacterial species isolated from deep sea brine pools of the Red Sea and provides in-depth insights into the possible mechanisms of apoptosis induced by the extracts in various human cancer cell lines. Overall, six extracts from Chromohalobacter salexigens (P3-86A, K-30, P3-86B(2)), Halomonas meridian (P3-37B), Idiomarina loihiensis (P3-37C), and Chromohalobacter israelensis (K-18) have displayed significant anticancer activities and can be further explored for isolation and characterization of bioactive molecules. This study also provides conclusive evidence that brine pools of the Red sea harbor several species of bacteria producing anticancer secondary metabolites.

\section{Abbreviations}

CTD: Conductivity-temperature-depths; TFF: Tangential flow filtration; DMEM: Dulbecco's modified eagle's medium; FCS: Fetal calf serum; OD: Optical density; MTT: 3-(4, 5-Dimethylthiazol-2-yl)-2, 5-

diphenyltetrazolium bromide; PS: Phosphatidylserine; HeLa: Cervical carcinoma; MCF-7: Breast adenocarcinoma; DU145: Prostate carcinoma; MMP: Mitochondrial membrane potential; PARP: Poly(ADP-ribose) polymerase.

\section{Competing interest}

The authors declare that they have no competing interests.

\section{Authors' contribution}

SS and MK planned the study, wrote manuscript and performed experiments along with LE. TH and GH isolated the strains and provided taxonomic classification of the bacterial strains. KH was responsible for growth of the strains in large batches. US was responsible for the planning of the expedition and the cultivation experiments, provided general coordination of the study and helped in manuscript writing. VBB provided general coordination of the study. All authors read and approved the final manuscript.

\section{Acknowledgments}

The authors are very grateful to the generous funding by the SEDCO Research Excellence project to US and VB, from which this study was partly funded. MK is fully funded and SS is partly funded by the KAUST CBRC Base Funds. LE is funded by the KAUST research grant of John A.C. Archer.

\section{Author details}

'Computational Bioscience Research Center, King Abdullah University of Science and Technology (KAUST), Thuwal 23955-6900, Kingdom of Saudi Arabia. ${ }^{2}$ Red Sea Research Center, King Abdullah University of Science and Technology (KAUST), Thuwal 23955-6900, Kingdom of Saudi Arabia.

Received: 5 September 2013 Accepted: 28 November 2013 Published: 5 December 2013

\section{References}

1. Newman DJ, Cragg GM: Natural products as sources of new drugs over the 30 years from 1981 to 2010. J Nat Prod 2012, 75:311-335.

2. Kinghorn AD, Chin YW, Swanson SM: Discovery of natural product anticancer agents from biodiverse organisms. Curr Opin Drug Discov Devel 2009, 12:189-196.

3. Laatsch $\mathrm{H}$ : AntiBase, a Database for rapid dereplication and structure determination of microbial natural products. In Book AntiBase, a Database for rapid dereplication and structure determination of microbial natural products. Edited by Editor ed.^eds. Weinheim, Germany: Wiley-VCH; 2010.

4. Newman DJ, Cragg GM: Marine natural products and related compounds in clinical and advanced preclinical trials. J Nat Prod 2004, 67:1216-1238.

5. Newman DJ, Cragg GM: Natural products as sources of new drugs over the last 25 years. J Nat Prod 2007, 70:461-477. 
6. Tan LT: Bioactive natural products from marine cyanobacteria for drug discovery. Phytochemistry 2007, 68:954-979.

7. Fenical W, Jensen PR, Palladino MA, Lam KS, Lloyd GK, Potts BC: Discovery and development of the anticancer agent salinosporamide A (NPI-0052). Bioorg Med Chem 2009, 17:2175-2180.

8. Gulder TA, Moore BS: Chasing the treasures of the sea - bacterial marine natural products. Curr Opin Microbiol 2009, 12:252-260.

9. Skropeta D: Deep-sea natural products. Nat Prod Rep 2008, 25:1131-1166.

10. Russo P, Nastrucci C, Cesario A: From the sea to anticancer therapy. Curr Med Chem 2011, 18:3551-3562

11. Thornburg CC, Zabriskie TM, MCPhail KL: Deep-sea hydrothermal vents: potential hot spots for natural products discovery? J Nat Prod 2010, 73:489-499.

12. Kameyama T, Takahashi A, Kurasawa S, Ishizuka M, Okami Y, Takeuchi T, Umezawa H: Bisucaberin, a new siderophore, sensitizing tumor cells to macrophage-mediated cytolysis. I. Taxonomy of the producing organism, isolation and biological properties. J Antibiot (Tokyo) 1987, 40:1664-1670.

13. Homann W, Sandy M, Tincu JA, Templeton AS, Tebo BM, Butler A: Loihichelins A-F, a suite of amphiphilic siderophores produced by the marine bacterium Halomonas LOB-5. J Nat Prod 2009, 72:884-888.

14. Li D, Wang F, Xiao X, Zeng X, Gu QQ, Zhu W: A new cytotoxic phenazine derivative from a deep sea bacterium Bacillus sp. Arch Pharm Res 2007, 30:552-555.

15. Sagar S, Esau L, Hikmawan T, Antunes A, Holtermann K, Stingl U, Bajic VB, Kaur M: Cytotoxic and apoptotic evaluations of marine bacteria isolated from brine-seawater interface of the Red Sea. BMC Complement Altern Med 2013, 13:29.

16. Al-Rikabi A, Husain S: Increasing prevalence of breast cancer among Saudi patients attending a tertiary referral hospital: a retrospective epidemiologic study. Croat Med J 2012, 53:239-243.

17. Rabah DM, Arafa MA: Prostate cancer screening in a Saudi population: an explanatory trial study. Prostate Cancer Prostatic Dis 2010, 13:191-194.

18. Sait K, Bentley J, Anfinan N, Power P: Cervical cancer prevention in Saudi Arabia: it is time to call for action! Open Women's Health J 2012, 6:1-5.

19. Backer $H$, Schoell M: New deeps with brines and metalliferous sediments in the Red Sea. Nat Physic Sci 1972, 240:153-158.

20. Antunes A, Ngugi DK, Stingl U: Microbiology of the Red Sea (and other) deep-sea anoxic brine lakes. Environ Microbiol Reports 2011, 3:416-433.

21. Hartmann M, Scholten J, Stoffers P, Wehner F: Hydrographic structure of brine-filled deeps in the Red Sea-new results from the Shaban, Kebrit, Atlantis II, and Discovery Deep. Mar Geol 1998, 144:311-330.

22. Kaye JZ, Márquez MC, Ventosa A, Baross JA: Halomonas neptunia sp. nov. Halomonas sulfidaeris sp. nov., Halomonas axialensis sp. nov. and Halomonas hydrothermalis sp. nov.: halophilic bacteria isolated from deep-sea hydrothermal-vent environments. Int I System Evol Microbiol 2004, 54:499-511.

23. Hou S, Saw JH, Lee KS, Freitas TA, Belisle C, Kawarabayasi Y, Donachie SP, Pikina A, Galperin MY, Koonin EV, et al: Genome sequence of the deep-sea gamma-proteobacterium Idiomarina loihiensis reveals amino acid fermentation as a source of carbon and energy. Proc Natl Acad Sci U S A 2004, 101:18036-18041.

24. Hua N-P, Hamza-Chaffai A, Vreeland RH, Isoda H, Naganuma T: Virgibacillus salarius sp. nov., a halophilic bacterium isolated from a Saharan salt lake. Int J Syst Evol Microbiol 2008, 58:2409-2414.

25. Wang $Y-X$, Wang Z-G, Liu J-H, Chen Y-G, Zhang X-X, Wen M-L, Xu L-H, Peng Q, Cui X-L: Sediminimonas qiaohouensis gen. nov., sp. nov., a member of the Roseobacter clade in the order Rhodobacterales. Int I Syst Evol Microbiol 2009, 59:1561-1567.

26. Copeland A, O'Connor K, Lucas S, Lapidus A, Berry KW, Detter JC, Del Rio TG, Hammon N, Dalin E, Tice H, et al: Complete genome sequence of the halophilic and highly halotolerant Chromohalobacter salexigens type strain (1H11(T)). Stand Genomic Sci 2011, 5:379-388.

27. Saum SH, Pfeiffer F, Palm P, Rampp M, Schuster SC, Muller V, Oesterhelt D: Chloride and organic osmolytes: a hybrid strategy to cope with elevated salinities by the moderately halophilic, chloride-dependent bacterium Halobacillus halophilus. Environ Microbiol 2013, 15:1619-1633.

28. Yin $Q$, Fu B, Li B, Shi X, Inagaki F, Zhang XH: Spatial variations in microbial community composition in surface seawater from the ultra-oligotrophic center to rim of the South Pacific Gyre. PLoS One 2013, 8:e55148.

29. Brettar I, Christen R, Hofle MG: Idiomarina baltica sp. nov., a marine bacterium with a high optimum growth temperature isolated from surface water of the central Baltic Sea. Int J Syst Evol Microbiol 2003, 53:407-413.

30. Qin $Q L$, Zhang XY, Wang XM, Liu GM, Chen XL, Xie BB, Dang HY, Zhou BC, Yu J, Zhang YZ: The complete genome of Zunongwangia profunda SM-A87 reveals its adaptation to the deep-sea environment and ecological role in sedimentary organic nitrogen degradation. BMC Genomics 2010, 11:247.

31. Arahal DR, Garcia MT, Ludwig W, Schleifer KH, Ventosa A: Transfer of Halomonas canadensis and Halomonas israelensis to the genus Chromohalobacter as Chromohalobacter canadensis comb. nov. and Chromohalobacter israelensis comb. nov. Int J Syst Evol Microbiol 2001, 51:1443-1448.

32. Gardes A, Kaeppel E, Shehzad A, Seebah S, Teeling H, Yarza P, Glockner FO, Grossart HP, Ullrich MS: Complete genome sequence of Marinobacter adhaerens type strain (HP15), a diatom-interacting marine microorganism. Stand Genomic Sci 2010, 3:97-107.

33. Ivanova EP, Romanenko LA, Chun J, Matte MH, Matte GR, Mikhailov W, Svetashev VI, Huq A, Maugel T, Colwell RR: Idiomarina gen. nov., comprising novel indigenous deep-sea bacteria from the Pacific Ocean, including descriptions of two species, Idiomarina abyssalis sp. nov. and Idiomarina zobellii sp. nov. Int J Syst Evol Microbiol 2000, 50(Pt 2):901-907.

34. Beech F, Davenport R: Isolation, purification and maintenance of yeasts. Meth Microbiol 1971, 4:153.

35. Dieffenbach CW, Dveksler G: PCR primer. Cold Spring Harbor, New York: Cold Spring Harbor Laboratory Press; 1995.

36. Zhang JH, Chung TD, Oldenburg KR: A simple statistical parameter for Use in evaluation and validation of high throughput screening assays. J Biomol Screen 1999, 4:67-73.

37. Dean E, Greystoke A, Ranson M, Dive C: Biomarkers of cell death applicable to early clinical trials. Exp Cell Res 2012, 318:1252-1259.

38. Soldani C, Scovassi Al: Poly(ADP-ribose) polymerase-1 cleavage during apoptosis: an update. Apoptosis 2002, 7:321-328.

39. Bouchard VJ, Rouleau M, Poirier GG: PARP-1, a determinant of cell survival in response to DNA damage. Exp Hematol 2003, 31:446-454.

40. Kaufmann SH, Desnoyers S, Ottaviano Y, Davidson NE, Poirier GG: Specific proteolytic cleavage of poly(ADP-ribose) polymerase: an early marker of chemotherapy-induced apoptosis. Cancer Res 1993, 53:3976-3985.

41. Tewari M, Quan LT, O'Rourke K, Desnoyers S, Zeng Z, Beidler DR, Poirier GG, Salvesen GS, Dixit VM: Yama/CPP32 beta, a mammalian homolog of CED3 , is a CrmA-inhibitable protease that cleaves the death substrate poly (ADP-ribose) polymerase. Cell 1995, 81:801-809.

42. Rogakou EP, Pilch DR, Orr AH, Ivanova VS, Bonner WM: DNA doublestranded breaks induce histone $\mathrm{H} 2 \mathrm{AX}$ phosphorylation on serine 139. Biol Chem 1998, 273:5858-5868.

43. Rogakou EP, Nieves-Neira W, Boon C, Pommier Y, Bonner WM: Initiation of DNA fragmentation during apoptosis induces phosphorylation of $\mathrm{H} 2 \mathrm{AX}$ histone at serine 139. J Biol Chem 2000, 275:9390-9395.

44. Danial NN, Korsmeyer SJ: Cell death: critical control points. Cell 2004, 116:205-219.

45. Dowsett M, Smith IE, Ebbs SR, Dixon JM, Skene A, Griffith C, Boeddinghaus I, Salter J, Detre S, Hills M, et al: Proliferation and apoptosis as markers of benefit in neoadjuvant endocrine therapy of breast cancer. Clin Cancer Res 2006, 12:1024s-1030s.

46. Thompson CB: Apoptosis in the pathogenesis and treatment of disease. Science 1995, 267:1456-1462.

47. Wong RS: Apoptosis in cancer: from pathogenesis to treatment. J Exp Clin Cancer Res 2011, 30:87.

48. Bitzer J, Grosse T, Wang L, Lang S, Beil W, Zeeck A: New aminophenoxazinones from a marine Halomonas sp.: fermentation, structure elucidation, and biological activity. J Antibiot (Tokyo) 2006, 59:86-92.

49. Ruiz-Ruiz C, Srivastava GK, Carranza D, Mata JA, Llamas I, Santamaria M, Quesada E, Molina IJ: An exopolysaccharide produced by the novel halophilic bacterium Halomonas stenophila strain B100 selectively induces apoptosis in human T leukaemia cells. Appl Microbiol Biotechnol 2011, 89:345-355.

50. Wang L, Grosse T, Stevens H, Brinkhoff T, Simon M, Liang L, Bitzer J, Bach G, Zeeck A, Tokuda H, Lang S: Bioactive hydroxyphenylpyrrole-dicarboxylic acids from a new marine Halomonas sp.: Production and structure elucidation. Appl Microbiol Biotechnol 2006, 72:816-822.

51. Donachie SP, Hou S, Gregory TS, Malahoff A, Alam M: Idiomarina loihiensis sp. nov., a halophilic gamma-Proteobacterium from the Lo'ihi submarine volcano, Hawai'i. Int J Syst Evol Microbiol 2003, 53:1873-1879. 
52. van der Horst MA, Stalcup TP, Kaledhonkar S, Kumauchi M, Hara M, Xie A, Hellingwerf KJ, Hoff WD: Locked chromophore analogs reveal that photoactive yellow protein regulates biofilm formation in the deep sea bacterium Idiomarina loihiensis. J Am Chem Soc 2009, 131:17443-17451.

53. Mutnuri S, Vasudevan N, Kastner M, Heipieper HJ: Changes in fatty acid composition of Chromohalobacter israelensis with varying salt concentrations. Curr Microbiol 2005, 50:151-154.

54. Vargas C, Jebbar M, Carrasco R, Blanco C, Calderon MI, Iglesias-Guerra F, Nieto $\mathrm{JJ}$ : Ectoines as compatible solutes and carbon and energy sources for the halophilic bacterium Chromohalobacter salexigens. J App/ Microbiol 2006, 100:98-107

55. Garcia-Estepa R, Argandona M, Reina-Bueno M, Capote N, Iglesias-Guerra F, Nieto JJ, Vargas C: The ectD gene, which is involved in the synthesis of the compatible solute hydroxyectoine, is essential for thermoprotection of the halophilic bacterium Chromohalobacter salexigens. J Bacteriol 2006, 188:3774-3784.

56. Zhao B, Lu W, Yang L, Zhang B, Wang L, Yang SS: Cloning and characterization of the genes for biosynthesis of the compatible solute ectoine in the moderately halophilic bacterium Halobacillus dabanensis D-8(T). Curr Microbiol 2006, 53:183-188.

57. Bergmann S, David F, Clark W, Wittmann C, Krull R: Membrane fluidity of halophilic ectoine-secreting bacteria related to osmotic and thermal treatment. Bioprocess Biosyst Eng 2013.

58. Ahn JW, Lee SY, Kim S, Kim SM, Lee SB, Kim KJ: Crystal structure of glucuronic acid dehydrogenase [correction of dehydrogeanse] from Chromohalobacter salexigens. Proteins 2012, 80:314-318.

59. Ahn JW, Lee SY, Kim S, Cho SJ, Lee SB, Kim KJ: Cloning, expression, purification, crystallization and X-ray crystallographic analysis of glucuronic acid dehydrogenase from Chromohalobacter salexigens. Acta Crystallogr Sect F Struct Biol Cryst Commun 2011, 67:689-691.

60. Ates $\mathrm{O}$, Oner ET, Arga KY: Genome-scale reconstruction of metabolic network for a halophilic extremophile, Chromohalobacter salexigens DSM 3043. BMC Syst Biol 2011, 5:12

61. Pastor JM, Bernal V, Salvador M, Argandona M, Vargas C, Csonka L, Sevilla A, Iborra JL, Nieto JJ, Canovas M: Role of central metabolism in the Osmoadaptation of the halophilic bacterium Chromohalobacter salexigens. J Biol Chem 2013, 288:17769-17781.

62. Konopleva M, Zhao S, Xie Z, Segall H, Younes A, Claxton DF, Estrov Z, Kornblau SM, Andreeff M: Apoptosis. Molecules and mechanisms. Adv Exp Med Biol 1999, 457:217-236.

63. Zou H, Li Y, Liu X, Wang X: An APAF-1.cytochrome c multimeric complex is a functional apoptosome that activates procaspase-9. J Biol Chem 1999, 274:11549-11556.

64. Schulze-Osthoff K, Ferrari D, Los M, Wesselborg S, Peter ME: Apoptosis signaling by death receptors. Eur J Biochem 1998, 254:439-459.

65. Micheau O, Tschopp J: Induction of TNF receptor I-mediated apoptosis via two sequential signaling complexes. Cell 2003, 114:181-190.

66. Samraj AK, Keil E, Ueffing N, Schulze-Osthoff K, Schmitz I: Loss of caspase-9 provides genetic evidence for the type I/II concept of CD95-mediated apoptosis. J Biol Chem 2006, 281:29652-29659.

67. Mcllwain DR, Berger T, Mak TW: Caspase functions in cell death and disease. Cold Spring Harb Perspect Med 2013, 3:a008656.

68. van Engeland M, Nieland $\amalg$, Ramaekers FC, Schutte B, Reutelingsperger CP. Annexin V-affinity assay: a review on an apoptosis detection system based on phosphatidylserine exposure. Cytometry 1998, 31:1-9.

69. D'Sa-Eipper C, Leonard JR, Putcha G, Zheng TS, Flavell RA, Rakic P, Kuida K, Roth KA: DNA damage-induced neural precursor cell apoptosis requires p53 and caspase 9 but neither Bax nor caspase 3. Development 2001, 128:137-146.

70. Shi Y: Activation of initiator caspases: history, hypotheses, and perspectives. J Cancer Mol 2005, 1:9-18.

71. Boulares AH, Yakovlev AG, Ivanova V, Stoica BA, Wang G, lyer S, Smulson M: Role of poly(ADP-ribose) polymerase (PARP) cleavage in apoptosis. Caspase 3-resistant PARP mutant increases rates of apoptosis in transfected cells. J Biol Chem 1999, 274:22932-22940.

72. Wang ZQ, Stingl L, Morrison C, Jantsch M, Los M, Schulze-Osthoff K, Wagner EF: PARP is important for genomic stability but dispensable in apoptosis. Genes Dev 1997, 11:2347-2358.

73. Salvesen GS, Dixit VM: Caspases: intracellular signaling by proteolysis. Cell 1997, 91:443-446.
74. Germain M, Affar EB, D'Amours D, Dixit VM, Salvesen GS, Poirier GG: Cleavage of automodified poly(ADP-ribose) polymerase during apoptosis. Evidence for involvement of caspase-7. J Biol Chem 1999, 274:28379-28384.

75. Leist M, Single B, Kunstle G, Volbracht C, Hentze H, Nicotera P: Apoptosis in the absence of poly-(ADP-ribose) polymerase. Biochem Biophys Res Commun 1997, 233:518-522.

76. Stefanis L, Park DS, Yan CY, Farinelli SE, Troy CM, Shelanski ML, Greene LA: Induction of CPP32-like activity in PC12 cells by withdrawal of trophic support. Dissociation from apoptosis. J Bio/ Chem 1996, 271:30663-30671.

77. Cryns VL, Bergeron L, Zhu H, Li H, Yuan J: Specific cleavage of alpha-fodrin during Fas- and tumor necrosis factor-induced apoptosis is mediated by an interleukin-1beta-converting enzyme/Ced-3 protease distinct from the poly (ADP-ribose) polymerase protease. J Biol Chem 1996, 271:31277-31282.

78. Herceg Z, Wang ZQ: Failure of poly(ADP-ribose) polymerase cleavage by caspases leads to induction of necrosis and enhanced apoptosis. Mol Cell Biol 1999, 19:5124-5133.

79. Mah LJ, El-Osta A, Karagiannis TC: GammaH2AX: a sensitive molecular marker of DNA damage and repair. Leukemia 2010, 24:679-686.

80. Clingen PH, Wu JY, Miller J, Mistry N, Chin F, Wynne P, Prise KM, Hartley JA Histone $\mathrm{H} 2 \mathrm{AX}$ phosphorylation as a molecular pharmacological marker for DNA interstrand crosslink cancer chemotherapy. Biochem Pharmacol 2008, 76:19-27.

81. Wilson AJ, Holson E, Wagner F, Zhang YL, Fass DM, Haggarty SJ, Bhaskara S, Hiebert SW, Schreiber SL, Khabele D: The DNA damage mark pH2AX differentiates the cytotoxic effects of small molecule HDAC inhibitors in ovarian cancer cells. Cancer Biol Ther 2011, 12:484-493.

82. Cheung-Ong K, Giaever G, Nislow C: DNA-damaging agents in cancer chemotherapy: serendipity and chemical biology. Chem Biol 2013, 20:648-659.

doi:10.1186/1472-6882-13-344

Cite this article as: Sagar et al:: Induction of apoptosis in cancer cell lines by the Red Sea brine pool bacterial extracts. BMC Complementary and Alternative Medicine 2013 13:344.

\section{Submit your next manuscript to BioMed Central and take full advantage of:}

- Convenient online submission

- Thorough peer review

- No space constraints or color figure charges

- Immediate publication on acceptance

- Inclusion in PubMed, CAS, Scopus and Google Scholar

- Research which is freely available for redistribution 